Agro-Science Journal of Tropical Agriculture, Food, Environment and Extension Volume 18 Number 3 (September 2019) pp. 19-24

ISSN 1119-7455

\title{
DETERMINANTS OF ADOPTION OF RISK MANAGEMENT STRATEGIES IN ELECTRONIC BANKING AMONG AGRO-ENTREPRENEURS IN UGHELLI NORTH LOCAL GOVERNMENT AREA OF DELTA STATE, NIGERIA
}

\author{
"Ugwuja V.C. and Onavwie O. \\ Department of Agricultural Economics \& Extension, University of Port Harcourt, Nigeria \\ *Corresponding author's email: vivian.ugwuja@uniport.edu.ng
}

\begin{abstract}
This study examined the determinants of adoption of risk management strategies in electronic banking (digital finance) among agro entrepreneurs in Ughelli North local Government area of delta state, Nigeria. Data were collected with the aid of structured questionnaire, administered on 79 respondents using two-stage sampling procedure. The data were analyzed with the use of descriptive statistics and regression analysis. This study showed that $34.0 \%$ of the respondents were male while $57.0 \%$ of the respondents were female, $39.2 \%$ of the respondents were in the age bracket of 41-50 years. The regression result shows that gender, age, marital status, level of education, farming status were all significant factors that influence risk management strategies in electronic banking. Household size, business experience, income and savings were not significant. Also, it was found that constraints faced by agro entrepreneur in adopting these risk management strategies includes the length of time it takes for unsuccessful funds transfer to be returned, the delayed response of banks to issues relating to electronic banking risks, ATM are not readily available and the ones that are, are usually congested resulting to agro entrepreneurs using the ATM at odd hours, amongst others. Proper awareness on these risk management strategies should be given to these rural entrepreneurs, and government should charge banks with the sole responsibility of providing a more secure and coordinated methods of carrying out these activities.
\end{abstract}

Key words: digital finance, electronic banking risks, ATM and cyber security

\section{INTRODUCTION}

Electronic Banking also known as digital finance is defined as "the use of technology to communicate instructions and receive information from a financial institution where an account is held. This service includes the system that enables customers of financial institution, individuals or businesses to access accounts, transact business, or obtain information on financial products and services through a public or private network" (Abdul and Muhammad, 2013). It has experienced tremendous growth in many countries especially Africa and today, it has transformed the traditional banking practice in Nigeria. Electronic banking in Nigeria has changed the way services are delivered by the banking sectors to their customers. Electronic banking services, has lower operating costs, improves customer services delivery, retains customers, reduces branch traffics, and downsize the number of branch staff (Parisa, 2006). Essentially, through the use of Information and Communication Technology banks now employ different channels such as online banking, mobile banking and Automated Teller Machine to deliver their services. Report on Electronic banking system in Nigeria reveals that e-payment machinery, especially the card technology, is presently enjoying the highest popularity in Nigerian banking market. To be competitive in the internet business, financial institutions need to harness the power of the internet successfully (Adewuyi, 2011). Hence it is important to understand the benefits, barriers and impediments as it relates to electronic banking services marketing in developing economies such as Nigeria. Despite the fact that this technology is a good one, it comes with so many risks. These risks caused by this phenomenon include hacking of servers and security breach, agro entrepreneurs, employees and customers' unfamiliarity with new technology, lack of infrastructures necessary to provide E-services, not taking an appropriate strategic approach by bank managers and by governmental top managers are challenges facing banks and financial institutions. One of the most important responsibilities of agro entrepreneurs is to understand these risks and the risk managements strategies associated to electronic banking. Risk management can be described as the process of determining the maximum acceptable level of overall risk of engaging in a proposed activity. It involves using risk assessment techniques to determine the initial level of risk and, if it is

Please cite as: Ugwuja V.C. and Onavwie O. (2019). Determinants of adoption of risk management strategies in electronic banking among agro-entrepreneurs in Ughelli North Local Government Area of Delta State, Nigeria Agro-Science, 18 (3), 19-24. DOI: https://dx.doi.org/10.4314/as.v18i3.4 
excessive, developing a strategy to ameliorate appropriate individual risks until the overall level is reduced to an acceptable level. Risk management approaches differ from one firm to the next, which partly reflects different risk management goals. The rapid spread of Internet banking all over Nigeria is its acceptance as an extremely cost effective delivery channel of banking services as compared to other existing channels. However, the introduction of electronic banking is not an unmixed blessing to agro entrepreneur, along reduction in cost of transactions, it has also brought about the exposure of these gullible agro entrepreneurs to risks and even new forms of risks to which banks conducting e-banking expose these entrepreneurs to. Regulators and supervisors all over the world are concerned that while banks should remain efficient and cost effective, they must be conscious of different types of risks this form of banking entails and have systems in place to manage the same (Solanki, 2012). This study is aimed at looking at those factors that can be adopted by agro entrepreneurs to reduce or combat these risks associated with electronic banking.

\section{Objectives of the Study}

The main objective of the study is to analyze the determinants of adoption of risk management strategy in electronic banking (e-banking) among agro entrepreneur in Ughelli North Local Government Area (LGA), Delta State. The specific objectives were to (i) describe the socio-economic characteristics of agro-entrepreneurs in Ughelli North LGA (ii) identify the various sources of risk faced by agro-entrepreneurs in accessing e-banking products and services in the study area, (iii) identify electronic banking risk management strategies adopted by agro entrepreneurs in the study area, (iv) examine the socio-economic factors that influence adoption of e-banking risk management strategies among agro-entrepreneurs in the study area, and (v) examine constraints to adoption of e banking risk management strategies among agro-entrepreneur in the study area.

\section{Hypothesis of the Study}

$\mathbf{H}_{\mathbf{0}}$ : There is no significance relationship between socio-economic characteristics of agro entrepreneur and adoption of electronic banking risk management strategies.

\section{MATERIALS AND METHODS}

The study was conducted in Ughelli North LGA in Delta State, located at coordinates latitude $9^{\circ} 45 \mathrm{~N}$ and longitude $8^{\circ} 43 \mathrm{E}$, with headquarters in the city of Ughelli. This LGA occupies a geographical area of $818 \mathrm{~km}^{2}$. According to the National Population Census of Nigeria (NPC, 2006), it has a population of 321,028 , the LGA has a total number of 17 communities which includes among others
Afiesere, Ekuigbo, Ekrejebor, Eruemukobwarien, Iwhremaro, Iwhreneneiwhaeorie, Ododegho and Odovie. The people in this area mostly involve in agricultural activities such as farming, processing of agro-products, buying and selling of agroproducts. Two-stage sampling was used to select respondents. Stage one was a purposive selection of four communities who have access to banking facilities. Stage two involved the purposive selection of 20 respondents who access electronic banking products from each community, which made it a total 80 respondents for the study, but 79 copies of questionnaire were used for the analysis. The data for this study were collected from primary source with the aid of questionnaire which was objective oriented. Objectives i,ii, iii and v were achieved using descriptive statistics such as frequencies and percentages, while objective iv was aachieved using regression analysis.

\section{Model Specification}

Regression analysis was used to test for significant relationship between socioeconomic characteristics of the agro entrepreneurs and the level of adoption of risk management strategies. The implicit form of the linear regression is:

$$
\text { Y-F }\left(X_{1}, X_{2}, X_{3}, X_{4}, X_{5}, X_{6}, X_{7}, X_{8}, X_{9}\right)+e \text {, }
$$

where $Y$ is the level of adoption of risk management strategies, $\mathrm{Y}$ was derived as $\mathrm{U} / \mathrm{V} \times$ $100, \mathrm{U}$ is number of risk management strategies adopted by an agro entrepreneur, $\mathrm{V}$ is total number of risk management strategies $\mathrm{X}_{1}$ is age of the agro entrepreneur (years), $\mathrm{X}_{2}$ is educational level (Years), $\mathrm{X}_{3}$ is marital status $(0=$ single, $1=$ married $), X_{4}$ is gender ( $0=$ male, $1=$ female $), X_{5}$ is business experience of the agro entrepreneur (years), $\mathrm{X}_{6}$ is personal annual income of the agro entrepreneurs ( $), X_{8}$ is annual savings ( $)$, and e is error term. The relationship between the dependent and each of the independent variable was examined using the four functional forms, linear, semi-log exponential and double log.

\section{Linear Function \\ $\mathrm{Y}=\mathrm{B}_{0}+1 \mathrm{~B}_{1} \mathrm{XB}_{1}+\mathrm{B}_{2} \mathrm{X}_{2}+\mathrm{B}_{3} \mathrm{X}_{3}+\mathrm{B}_{4} \mathrm{X}_{4}+\mathrm{B}_{5} \mathrm{X}_{5}+$ $\mathrm{B}_{6} \mathrm{X}_{6}+\mathrm{B}_{7} \mathrm{X}_{7}+\mathrm{B}_{8} \mathrm{X}_{8}+\mathrm{B}_{9} \mathrm{X}_{9}+\mathrm{e}$}

\section{Exponential Function}

$\mathrm{Y}=\mathrm{B}_{0}+\mathrm{B}_{1} \log \mathrm{X}_{1}+\mathrm{B}_{2} \log \mathrm{X}_{2}+\mathrm{B}_{3} \log \mathrm{X}_{3}+$ $\mathrm{B}_{4} \log \mathrm{X}_{4}+\mathrm{B}_{5} \log \mathrm{X}_{5}+\mathrm{B}_{6} \log \mathrm{X}_{6}+\mathrm{B}_{7} \log \mathrm{X}_{7}+$ $\mathrm{B}_{8} \log \mathrm{X}_{8}+\mathrm{B}_{9} \mathrm{X}_{9}+\mathrm{e}$

Semi -Log Function:

$\log \mathrm{Y}=\mathrm{B}_{0}+\mathrm{B}_{1} \mathrm{X}_{1}+\mathrm{B}_{2} \mathrm{X}_{2}+\mathrm{B}_{3} \mathrm{X}_{3}+\mathrm{B}_{4} \mathrm{X}_{4}+\mathrm{B}_{5} \mathrm{X}_{5}+$ $\mathrm{B}_{6} \mathrm{X}_{6}+\mathrm{B}_{7} \mathrm{X}_{7}+\mathrm{B}_{8} \mathrm{X}_{8}+\mathrm{e}$

Double-Log Function

$\log \mathrm{Y}_{=} \mathrm{B}_{0}+\mathrm{B}_{1} \log \mathrm{B}_{1} \mathrm{X}_{1}+\mathrm{B}_{2} \log \mathrm{B}_{2} \mathrm{X}_{2}+\mathrm{B}_{3} \log \mathrm{B}_{3} \mathrm{X}_{3}+\mathrm{B}$ ${ }_{4} \log B_{4} X_{4}+B_{5} \log B_{5} X_{5}+B_{6} \log B_{6} X_{6}+B_{7} \log B_{7} X_{7}+$ $\mathrm{B}_{8} \log _{8} \mathrm{X}_{8}+\mathrm{e}$ 
where $\mathrm{B}_{0}$ is intercept, $\mathrm{B}_{1}$ to $\mathrm{B}_{8}$ are estimated coefficients. The criteria used in selecting the functional equation that will best fit for regression were highest $\mathrm{R}^{2}$ value, highest number of significant variables, highest F-value and conformity to apriority expectations of the coefficient.

\section{RESULTS AND DISCUSSION Socio-Economic Characteristics of Agro-Based Entrepreneurs}

The socio-economic characteristics of the respondents were summarized in Table 1. The results show a slightly higher ratio for females than males. This showed that $43.0 \%$ of the respondents were male while $57.0 \%$ of the respondents were females. The study also revealed that $39.2 \%$ of the

Table 1: Distribution of farmers' socio-economic characteristics

\begin{tabular}{|c|c|c|}
\hline Socio-economic characteristics & $\begin{array}{c}\text { Frequency } \\
(n=79)\end{array}$ & $\begin{array}{c}\text { Percentage } \\
(\%)\end{array}$ \\
\hline \multicolumn{3}{|l|}{ Gender } \\
\hline Male & 34 & 43.0 \\
\hline Female & 45 & 57.0 \\
\hline $21-30$ & 12 & 15.2 \\
\hline $31-40$ & 19 & 24.1 \\
\hline $41-50$ & 31 & 39.2 \\
\hline $51-60$ & 13 & 16.5 \\
\hline $61-70$ & 4 & 5.1 \\
\hline \multicolumn{3}{|l|}{ Marital status } \\
\hline Single & 19 & 24.1 \\
\hline Married & 51 & 64.6 \\
\hline Widowed & 7 & 8.9 \\
\hline Divorced & 2 & 2.6 \\
\hline \multicolumn{3}{|l|}{ Level of educational status } \\
\hline No formal education & 2 & 2.5 \\
\hline Primary & 11 & 13.9 \\
\hline Secondary & 29 & 36.7 \\
\hline Tertiary & 35 & 44.3 \\
\hline Others & 2 & 2.5 \\
\hline \multicolumn{3}{|l|}{ Family size } \\
\hline $1-3$ & 18 & 22.8 \\
\hline $4-6$ & 51 & 64.6 \\
\hline $7-10$ & 10 & 12.7 \\
\hline \multicolumn{3}{|l|}{ Farming status } \\
\hline Full time & 46 & 58.2 \\
\hline Part time & 33 & 41.8 \\
\hline \multicolumn{3}{|l|}{ Enterprise type } \\
\hline Livestock & 18 & 22.8 \\
\hline Crop farming & 17 & 21.5 \\
\hline Agro processing & 2 & 2.5 \\
\hline Fish farming & 22 & 27.8 \\
\hline Marketing & 16 & 20.3 \\
\hline Others & 4 & 5.1 \\
\hline \multicolumn{3}{|l|}{ Business experience } \\
\hline $1-10$ & 62 & 78.5 \\
\hline $11-20$ & 14 & 17.7 \\
\hline $21-30$ & 1 & 1.3 \\
\hline $31-40$ & 2 & 2.5 \\
\hline \multicolumn{3}{|l|}{ Average monthly income (\#) } \\
\hline $10,000-50,000$ & 3 & 3.8 \\
\hline $60,000-500,000$ & 50 & 63.3 \\
\hline $600,000-1,000,000$ & 12 & 15.2 \\
\hline $1,100,000-1,500,000$ & 2 & 7.6 \\
\hline $1,600,000-2,000,000$ & 6 & 7.6 \\
\hline $2,100,000-2,500,000$ & 2 & 2.5 \\
\hline $2,600,000-3,000,000$ & 4 & 5.1 \\
\hline \multicolumn{3}{|l|}{ Annual savings (\#) } \\
\hline $10,000-200,000$ & 65 & 82.3 \\
\hline $210,000-400,000$ & 7 & 8.9 \\
\hline $410,000-800,000$ & 4 & 5.1 \\
\hline $801,000-1.000 .000$ & 2 & 2.5 \\
\hline
\end{tabular}

Field survey, 2018 respondents were in the age bracket of 41-50 and $24.1 \%$ were observed to be in the age bracket of $31-40$, which indicates that the respondents were in the middle and active ages of production. Married individuals were the highest among the respondents with the percentage of $64.6 \%$, followed by single with the percentage $24.1 \%$ while $8.9 \%$ were widowed, and $2.6 \%$ divorced. A breakdown of the education statistics indicates that $2.5 \%$ had no formal education, $13.9 \%$ had attained the primary education, and $44.3 \%$ of the respondents had attained tertiary education and this was the highest level of education attained by my respondents, followed closely by $36.7 \%$ of the respondents who had attained secondary education, which is quite appropriate because a good level of education should be attained in other to be able to operate or use most of the electronic products and services. About $64.6 \%$ had a family size of $4-6,22.8 \%$ had a family size of $1-3$, and family size of $7-10$ having a percentage of $12.7 \%$ which showed that the family size of 4-6 were the most dominant in the area of study hence they had the highest frequency. The respondents which were into agribusiness fulltime were the most dominant in the study with a percentage of $58.2 \%$ while $41.8 \%$ were part-time agro entrepreneurs. About $27.8 \%$ of these respondents were into fish farming, $22.8 \%$ were into livestock production, $21.5 \%$ were into crop farming, $20.3 \%$ were into marketing of agricultural products while $2.5 \%$ focused on agro processing.

\section{Sources of Risk Faced by Agro-Entrepreneurs} in Accessing e-banking Products and Services

The sources of risks faced by the agro entrepreneurs in Ughelli north local government are summarized in Table 2. The result showed that $67.1 \%$ of the respondent agreed that they have faced risk in the form of text message requesting for their bank details, which they sent and from which their accounts were hacked and money withdrawn. This is one of the most prominent forms of risk because hackers now send phishing messaging at random for people awaiting those who fall victims. About $63.3 \%$ of the respondents accepted that they were accosted by criminals immediately after withdrawal from automated teller machines (ATM).This is as a result of the customers using ATM at odd hours in a bid to avoid long queue, thereby making them susceptible to hoodlums and criminals. About $51.9 \%$ of the agro entrepreneurs in the study area further stated that they had fallen victim to text messages from criminals who claimed that their ATM card is expired or due for renewal, requesting for the sensitive security numbers on the card from which their money was withdrawn. The same percentage of people also said they had suffered from failed transactions when using their bank application, these transactions were thought to have failed due to 
Table 2: Sources of risk faced by agro-entrepreneurs in accessing e-banking products and services

\begin{tabular}{|c|c|c|}
\hline Sources of risks & Frequency & Percentage \\
\hline $\begin{array}{l}\text { Similar email address with that of the bank that requested for customers details from which accounts were } \\
\text { hacked }\end{array}$ & 9 & 11.8 \\
\hline Text message requesting for customers bank details, from which account was hacked and money withdrawn & 53 & 67.1 \\
\hline Fake website which when accessed leads to hacking of my device and exposure of my bank details & 7 & 8.9 \\
\hline ATM card and security number was accessed by $3^{\text {rd }}$ party & 33 & 41.8 \\
\hline Accosted by criminals immediately after withdrawal from the automated teller machine (ATM) & 50 & 63.3 \\
\hline Text messages saying ATM CARD had expired, requesting for the security numbers on the card & 41 & 51.9 \\
\hline $\begin{array}{l}\text { Failed transactions done with banks mobile application due to network issues, but money was debited from } \\
\text { my account }\end{array}$ & 41 & 51.9 \\
\hline Bad and negatives comments from my friends and family hindered me from continuing with these platforms & 7 & 8.9 \\
\hline Stress passed through in the bank in other to get back money lost due to transfer failures & 23 & 29.1 \\
\hline Error message every time I try to make transactions using my banks short code & 12 & 15.2 \\
\hline $\begin{array}{l}\text { Similar email address with that of the bank requesting for change of online banking password, which led to } \\
\text { hacking of my account }\end{array}$ & 5 & 6.3 \\
\hline Stolen phone resulting to loss of access to my online banking platform & 8 & 10.1 \\
\hline Fake online shopping site, where details of debit card entered resulted to loss of my money & 6 & 7.6 \\
\hline Payments made on point on sales (POS) which wasn't approved, yet money was deducted from my account & 20 & 25.5 \\
\hline $\begin{array}{l}\text { Unknown call from someone claiming to be account manager, requesting for some details, which } \\
\text { compromised my account }\end{array}$ & 18 & 22.8 \\
\hline
\end{tabular}
Field survey, 2018

network issues but money was debited from their account. About $41.8 \%$ said that their ATM card was accessed by third party, this was corroborated by findings of Yousafzai et al. (2003) who reported that lack of security in protecting personal information is a problem in using internet banking according. About $29.1 \%$ of the respondent said that the stress faced in the bank in other to get back their funds which was lost due to using one or two banking services platform is their problem, whereas $25.5 \%$ suffered deduction of money on transactions not approved while using POINT ON SALES (POS). About $22.8 \%$ claimed to have received calls from unknown people claiming to be their account manager requesting for some sensitive details which lead to the compromising of their accounts.

Again 15.2\% indicated that the error messages they get when trying to access their bank short code is not encouraging, this is also due to network issues. Also $11.8 \%$ of the respondent reported that similar email address with that of their banks emailed them requesting for their banking details in other to perform upgrades from which their accounts were hacked. About $10.1 \%$ mentioned that loss of their phones which led to lack of access to their online banking platforms. About $8.9 \%$ agreed that fake websites which were accessed compromises their devices and leads to hacking of their accounts, same percentage also agreed that negative comments from friends and family about electronic banking was the issue they faced which lead to total mistrust in electronic banking. Finally $7.6 \%$ of the respondents indicated that fake online shopping site, where details of debit card were entered resulted to loss of their money.

\section{Risk Management Strategies Adopted by Agro Entrepreneurs}

Risk management strategies adopted by the agro entrepreneurs are shown (Table 3). Majority (92.4\%) of the respondents block and ignore irregular email and text messages that have to do with their bank details thereby preventing risk due to phishing, $87.5 \%$ said they no longer use lonely ATMs or go to the ATM at odd hours. About $73.4 \%$ indicated that they keep contact with their banks in relation to information got online or via SMS relating to their bank accounts. About 53.2\% indicated that since their experience with these risks they are now careful whenever they login to their online banking platform to prevent preying eyes. Whereas 50.6\% indicated they call their banks to deactivate their ATM card whenever lost, $45.6 \%$ said that they periodically check with their banks if everything is okay with their accounts in order to detect any move to hack their accounts. About $44.3 \%$ of the agro entrepreneurs agreed that they do not use birthdates and address that would be easy for attackers to find out. Also $44.3 \%$ indicated that not using the same passwords for all their bank account are both strategies they used in combating security risks. Whereas $30.4 \%$ of the respondents indicated that they no longer click on links from suspicious looking emails, $25.3 \%$ of them revealed they now use reliable mobile security software to protect their devices. About $22.8 \%$ of the respondent agreed that they download mobile apps only from official stores, while $11.4 \%$ reported that they always make use of https:// (which is more secured) instead of http:// while logging into websites. Finally $10.1 \%$ reported that they do not use public Wi-Fi for online transactions. 


\section{Socio-Economic Factors in Level of Adoption of Risk Management Strategies in e-Banking}

Results of the regression analysis for the socioeconomic characteristics for all the four functional forms are shown in Table 4. Double-log form was chosen as the lead equation based on the highest value of coefficient of multiple determination $\left(\mathrm{R}^{2}\right)$, more significant coefficients, highest F-value and conformity to theoretical expectations of the $\mathrm{R}^{2}$. The $\mathrm{R}^{2}$ value of 0.691 indicates that about $69 \%$ of the variation in the dependent variation was explained by the independent variable included in the regression while the remaining $31 \%$ was due to other factors not specified in the model; F-ratio with 5.693 value in the regression is significant at $1 \%$. It implies that all the variables have significant or joint effect on the dependent variables.

Gender $\left(X_{1}\right)$ was significant at $5 \%$ and related positively to level of adoption of risk management strategies in electronic banking. This shows that men were more likely to adopt to many risk management strategies. Age $\left(\mathrm{X}_{2}\right)$ was significant and had a negative coefficient. This implied that being a younger farmer increased the probability of adopting more risk management strategies in electronic banking. The negative effects of age may be due to younger farmers being technology savvy which helps to adopt to different risk management strategies. This is in line with the findings of Ugwuja et al. (2017) who reported that younger farmers adopted more risk management strategies in fish farming. Marital status $\left(\mathrm{X}_{3}\right)$ was significant at $5 \%$ and has positive coefficient.

This implied that being married increased the probability of level of adoption of risk management strategies. Level of education $\left(\mathrm{X}_{4}\right)$ was significant at $1 \%$ and it related positively to level of adoption of risk management strategies in electronic banking. This shows that the more literate a farmer is the more chances of adopting to many risk management strategies. Farming status $\left(\mathrm{X}_{6}\right)$ was significant at $5 \%$ and had a negative coefficient. This shows that being a full time farmer reduces the chances of adopting more of risk management strategies. This may be due to part-time agroentrepreneurs getting income from other sources and increasing their chances of having more resources that will enable them to adopt to more risk management strategies. Household size, business experience, income and savings were not significant.

Table 3: Risk management strategies adopted by agro entrepreneurs

\begin{tabular}{|c|c|c|}
\hline Risk managements strategies & Frequency & Percentage \\
\hline $\begin{array}{l}\text { I take special care whenever I want to login to my online banking platform to prevent preying } \\
\text { eyes from getting my details }\end{array}$ & 42 & 53.2 \\
\hline I ignore irregular email and Text messages that has anything to do with my bank details & 73 & 92.4 \\
\hline I no longer click on links in suspicious looking email no matter how enticing they look & 24 & 30.4 \\
\hline I contact my bank to crosscheck my information receive online or via text message & 58 & 73.4 \\
\hline I periodically check with my bank to confirm if everything is okay & 36 & 45.6 \\
\hline $\begin{array}{l}\text { I no longer use birthdates, address and other words or numbers that would be easier for attackers to find out } \\
\text { or guess my passwords }\end{array}$ & 35 & 44.3 \\
\hline $\begin{array}{l}\text { I don't use the same passwords for all my bank accounts because guessing of one password can } \\
\text { compromise the other accounts }\end{array}$ & 35 & 44.3 \\
\hline I don't use lonely ATMs or go to the ATM during late hours & 69 & 87.5 \\
\hline I now use a reliable mobile security software to protect my device & 20 & 25.3 \\
\hline I now use a two factor authentication(pin and OTP) process for my mobile banking & 18 & 22.8 \\
\hline I called my bank immediately to deactivate my misplaced ATM card & 40 & 50.6 \\
\hline I installed antivirus to prevent third party from accessing my computer or phone & 18 & 22.8 \\
\hline I don't use public Wi-Fi for my online transactions & 8 & 10.1 \\
\hline I always use https:// instead of http: to log in my account I download apps only from reputable & 29 & 11.4 \\
\hline Vendors & 18 & 22.8 \\
\hline
\end{tabular}

Table 4: Regression results on level of adoption of risk management strategies in e-banking by agro-entrepreneurs

\begin{tabular}{lllll}
\hline Variables & \multicolumn{1}{l}{ Linear } & Exponential & Semi-log & Double log \\
\hline Constant & $57.688(2.936)^{* * *}$ & $202.462(3.814)^{* * *}$ & $4.096(8.805)^{* * *}$ & $7.204(5.760)^{* * *}$ \\
Gender $\left(\mathrm{X}_{1}\right)$ & $0.146(1.358)$ & $0.203(1.908)^{*}$ & $0.164(1.541)$ & $0.226(2.163)^{* *}$ \\
Age $\left(\mathrm{X}_{2}\right)$ & $-0.518(-3.428)^{* * *}$ & $-0.586(-3.620)^{* * *}$ & $-0.480(-3.205)^{* * *}$ & $-0.575(-0.608)^{* * *}$ \\
Marital status $\left(\mathrm{X}_{3}\right)$ & $0.269(2.309)^{* *}$ & $0.266(2.053)^{* *}$ & $0.241(2.091)^{* *}$ & $0269(2.112)^{* *}$ \\
Level of education $\left(\mathrm{X}_{4}\right)$ & $0.402(3.684)^{* * *}$ & $0.386(3.496)^{* * *}$ & $0.394(3.651)^{* * *}$ & $0.392(3.611)^{* * *}$ \\
Household size $\left(\mathrm{X}_{5}\right)$ & $0.010(0.090)$ & $0.042(0.385)$ & $-0.028(-0.256)$ & $0.029(0.273)$ \\
Farming status $\left(\mathrm{X}_{6}\right)$ & $-0.181(-1.796)^{*}$ & $-0.183(-1.804)^{*}$ & $-0.217(-2.168)^{* *}$ & $-0.207(-2.068)^{* *}$ \\
Business & 0.046 & 0.072 & 0.034 & 0.066 \\
Experience $\left(\mathrm{X}_{7}\right)$ & $(0.355)$ & $(0.537)$ & $(0.262)$ & $(0.499)$ \\
Income $\left(\mathrm{X}_{8}\right)$ & $0.047(0.301)$ & $0.100(0.528)$ & $0.106(0.689)$ & $0.173(0.930)$ \\
Savings $\left(\mathrm{X}_{9}\right)$ & $-0.045(-0.300)$ & $-0.154(-0.847)$ & $-0.107(-0.718)$ & $-0.208(-1.160)$ \\
$\mathrm{R}^{2}$ & 0.667 & 0.656 & 0.688 & 0.691 \\
F-value & $5.431 * * *$ & $4.780 * * *$ & $5.204 * * *$ & $5.693 * * *$ \\
\hline Field Survey $(2018) ; * *$ Significant at 1\% level, ** Significant at 5\% level, *Significant at $10 \%$ level. Values in parenthesis are the t-values
\end{tabular}


Table 5: Constraints faced by agro-entrepreneurs in adopting risk management strategies in electronic banking Constraints

My bank doesn't always respond on time to issues concerning these risk

I do not have proper information from the bank or any other medium on how to go about these risks

The ATM are not really available in my locality and the ones that are available are usually crowded during the day, so I still result to waiting for odd hours before making withdrawal

I cannot operate most of these devices, making me always at risk since I call on people to help me use them

I can barely differentiate my banks email fromthese hackers because the bank do not have any uniqueness distinguishing theirs

There's no protection of customers privacy in our network providers because I think most of the time my details are gotten by their negligence not mine

Most of these fake websites are linked to my bank websites, which makes me always trust and fall for them without knowing

The security breach are usually as a result of the banks fault thereby exposing my details It takes long for unsuccessful fund transfer to be returned Field Survey (2018)

\begin{tabular}{ll} 
Frequency & Percentage \\
\hline 55 & 69.6 \\
39 & 49.9 \\
50 & 63.3 \\
& \\
26 & 32.9 \\
11 & 13.9 \\
& \\
10 & 12.7 \\
10 & \\
& 12.7 \\
10 & 12.7 \\
63 & 79.7
\end{tabular}

\section{Constraints Faced by Agro Entrepreneurs in Adopting Risk Management Strategies}

The constraints faced by agro entrepreneurs is summarized in Table 5, with $79.7 \%$ of the respondents revealing that the length it takes for unsuccessful transfer to be returned back to their account is too long. About $63.3 \%$ said that ATMs are not really available in their locality and the ones available are always crowded during the day so they still result to going to the ATM when it's lonely making them susceptible to this criminal. Whereas $49.9 \%$ of the respondent indicated that lack of information on what to do in times of risk is their issues, this is due to the lack of awareness banks do not create for their customers. Only $12.7 \%$ of the respondents said that there's no protection of their privacy in the network services, that's why hackers can get access to their details which they use in sending spam messages.

\section{CONCLUSION}

Electronic banking though very convenient has so much associated risks. Managing these risks is pertinent to effective use of electronic banking products. Findings from the study showed that that gender, age, marital status, level of education, farming status are the main factors determining level of adoption of risk management strategies in electronic banking among agro entrepreneur in my study area. Constraints faced by agro entrepreneur in adopting these risk management strategies includes the length it takes for unsuccessful funds transfer to be returned, the delayed response of banks to issues relating to electronic banking risks, the crowdedness of ATM available leading to their inability to access as at when due. The study recommends that Central Bank of Nigeria should charge banks with the responsibility of educating the customers, proper dispersal of knowledge on what these programs are, the risk involved and what methods can be used to combat them would be a bold step. It is also important for CBN toadopt a clear and relevant regulation that addresses electronic banking which will specify the need for banks to urgently attend to customers who are experiencing these risks.

\section{REFERENCES}

Abdul G.W. and Muhammad R. (2013). An opportunities and constraints in expending e-banking in developing countries. Interdisciplinary Journal of Contemporary Research in Business March, 4 (11), 11-12

Adewuyi I.D. (2011). Electronic banking in Nigeria: challenges of the regulatory authorities and the way forward. International Journal of Economic Development Research and Investment, 2 (1), 149-156

National Population Commission (2006). Nigeria 2006 Population Census Arranged by State. National Population Commission, Abuja, Nigeria

Parisa A. (2006). Adoption of e-Banking Services by Iranian Customers. Unpublished MSc Thesis. Lulea University of Technology, Division of Industrial Marketing and E-Commerce

Solanki V.S. (2012). Risks in e-banking and their management. International Journal of Marketing, Financial Services \& Management Research, 1 (3), 20-23

Ugwuja V.C., Dickson-Johnson P.M. and Familusi L.C (2017). Determinants of adoption level of risk management strategies by fish farmers in Degema Local Government Area of Rivers State, Nigeria. Agro-Science, 16 (2), 31-37

Yousafzai S., Pallister J. and Foxall G. (2003). A proposed model of e-trust for electronic banking. Technovation, 23 (11), 847-860 